\title{
Anti-predator adaptations in a great scallop (Pecten maximus) - a palaeontological perspective
}

\author{
Krzysztof Roman Brom, Krzysztof Szopa, Tomasz Krzykawski, Tomasz Brachaniec' Mariusz Andrzej Salamon ${ }^{\mathrm{A}^{*}}$
}

Krzysztof Roman Brom: Department of Paleontology and Stratigraphy, Faculty of Earth Sciences, University of Silesia in Katowice

Krzysztof Szopa: Department of Geochemistry, Mineralogy and Petrography, Faculty of Earth Sciences, University of Silesia in Katowice

Tomasz Krzykawski: Department of Geochemistry, Mineralogy and Petrography, Faculty of Earth Sciences, University of Silesia in Katowice

Tomasz Brachaniec: Department of Geochemistry, Mineralogy and Petrography, Faculty of Earth Sciences, University of Silesia in Katowice

Mariusz Andrzej Salamon: Department of Paleontology and Stratigraphy, Faculty of Earth Sciences, University of Silesia in Katowice*

Record

Internal durable microstructures in great scallop (Pecten maximus) shell probably record adaptations to increased predation pressure during the so-called Mesozoic Marine Revolution.

Abstract

Shelly fauna was exposed to increased pressure exerted by shell-crushing durophagous predators during the so-called Mesozoic Marine Revolution that was initiated in the Triassic. As a result of evolutionary 'arms race', prey animals such as bivalves, developed many adaptations to reduce predation pressure (e.g. they changed lifestyle and shell morphology in order to increase their mechanical strength). For instance, it was sug gested that Pectinidae had acquired the ability to actively swim to avoid predator attack during the early Mesozoic. However, pectinids are also know to have a specific shell microstructure that may effectively protect them against predators. For instance, we highlight that the shells of some recent pectinid species (e.g. Pecten maximus) that display cross-lamellar structures in the middle part playing a significant role in the energy dissipation, improve the mechanical strength. In contrast, the outer layers of these bivalves are highly porous, which allow them to swim more efficiently by reducing the shell weight. Pectinids are thus perfect examples of animals optimising their skeletons for several functions. We suggest that such an optimisation of their skeletons for multiple functions likely occurred as a results of increased predation pressure during the so-called Mesozoic Marine Revolution.

\section{Introduction}

Coevolution of various predators and Conchifera is a classic example of an 'arms race'. Such interdependence relies on the interaction between two groups of species, in which group A evolves appropriate adjustments to better exploit the species from group $B$, in response, group $B$ evolves better adaptation for efficient reduction of pressure from the species of group A (e.g. Futuyma, 2008; Krebs, 2011). In order to reduce pressure from predators, molluscs at the beginning of their evolutionary history needed to adopt many anti-predator strategies. It has been argued that the formation of a shell during the so-called "Cambrian explosion" was directly connected with the necessity of mechanical protection of tissues with impaired ability to regeneration (Bengtson \& Morris, 2009; Pokryszko, 2009; Jackson et al., 2010; Vendrasco et al., 2010). The shell of an early Conchifera was likely formed via the fusion of sclerites into larger structural units and then into a coherent shell, which increased the fossilisation potential of early molluscs.

During the periods of increased predation pressure, shells of some molluscs underwent substantial modifications (such as
Key words

Pecten maximus $\cdot$ shell $\cdot$ microstructure $\cdot$ adaptation $\cdot$ predation

Received: 5 December 2014 Accepted: 26 January 2015

thickening and covering by spines), which likely increased their mechanical strength and consequently provided better protection from predators (e.g. Vermeij, 1977, 1987; Kosnik et al., 2011), including flatworms, drilling gastropods, asteroids, crustaceans and carnivorous fish. In addition, development of appropriate microstructures occurring in shells is also thought to increase the mechanical strength (e.g. Ragaini \& Di Celma, 2009).

Adaptations in morphology and lifestyle in bivalve molluscs have a critical impact on their survival. For instance, by increasing the mechanical strength of shells, molluscs may significantly reduce the pressure from predators (e.g. Harper \& Skelton, 1993). During the periods of increased pressure from shell-crushing predators, such as during the Mesozoic Marine Revolution (MMR), many adaptions to durophagous and boring predation occurred in benthic organisms (Harper \& Skelton, 1993). For instance, some bivalves adopted an infaunal habit, using their siphons to gather nutrients from the sediment-water interface whilst remaining safe, the others evolved the ability to fuse to the substrate, which made them more difficult to consume by smaller predators. The latter adaptation occurred in some species of Ostreoida during the Late Triassic (Norian stage) referred 
to as the Early Mesozoic Marine Revolution (Salamon et al., 2012; Tackett \& Bottjer, 2012).

Shell of the molluscs is the product of mantle (pallium) and it is composed mainly of calcium carbonate (in the form of calcite and/or aragonite), which constitutes at least $95 \%$ of its weight and various biopolymers forming the organic matrix (e.g. DyduchFalinowska \& Piechocki, 1993; Barthelat et al., 2009; Piechocki, 2009; Katti et al., 2010; Meyers et al., 2011). It can be divided into three main structural layers. The outermost layer, called periostracum, is made mainly of conchiolin. The next (middle) layer (mesostracum) is mainly composed of calcium carbonate crystals. The third (inner) layer (hypostracum) is constructed by calcareous plates. The first two layers are generally formed by the edge of the mantle, whereas the third one on the entire surface of epithelial tissue (Urbański, 1989; Dyduch-Falinowska \& Piechocki, 1993; Jura, 2005; Piechocki, 2009).

Bivalves may be divided into two main ecological categories: (i) infaunal forms, which live within the sediment, and (ii) epifaunal forms, which live on the bottom substratum (Raup \& Stanley, 1984). Amongst epifaunal bivalves, three groups may be also distinguished: (i) species that attach to the substratum by an organic byssus spun (such as Mytilus edulis), (ii) species that attach to the hard substratum by cementing valve (such as many species of Ostreidae), and (iii) species that are free lying, some of them with the ability to swim (e.g. Pectinidae) (Harper \& Skelton, 1993).

The great scallop (Pecten maximus), so-called the king scallop, is a recent bivalve species belonging to Pteriomorphia bivalves of Ostreoida, order and Pectinidae family. This family has a very long and rich fossil record extending back to the Triassic period (e.g. Hautmann, 2010), which provides unique perspectives in understanding the impact of increased predation pressure on prey evolution. The unusual morphologies and (bio)geochemistry of the shell of this species have become an interest of many researchers (e.g. Cuif \& Dauphin, 1996; Chauvaud et al., 2005; Grefsrud et al., 2008). In this paper, we discuss the specific microstructure of this species in the context of anti-predatory adaptation.

\section{Shell microstructure of Pecten maximus}

The commercially available shell of a great scallop ( $P$. maximus) was fractured in order to show the microstructural details. The fracture was made parallel to the fins in the central part of the bottom valve (Figure $1 \mathrm{~A}$ and $\mathrm{B}$ ), where the body of an animal was present. The outer surface of the bottom valve was also fractured to show the microstructure of the ribs.

The microstructural morphology of the $P$. maximus shell was investigated using a scanning FET Philips 30 electron microscope (15 kV and $1 \mathrm{nA}$ ) at the Faculty of Earth Sciences, University of Silesia, Sosnowiec, Poland.

The investigated shell exhibits well-differentiated microstructures along its cross section. The outer surface of the bottom valve shows well-evident porous microstructure of the ribs (Figure $1 \mathrm{E}, \mathrm{F}$ ) consisting of numerous pores with a diameter ranging from 5 to $7 \mu \mathrm{m}$. Amount of pores is approximately 1300 per $1 \mathrm{~mm}^{3}$. The middle layer, in turn, displays the hierarchical crosslamellar structure (Figure 1 C, D).

\section{Discussion}

Defense mechanisms of prey against predator may be divided into two main groups - passive and active. Passive defenses are associated with morphological and anatomical adaptations, such as modifications in shell structure, whereas active defenses are related to direct responses to predator occurrence, for example, active escape or rapid burrowing (e.g. Harper \& Skelton, 1993). $P$. maximus exhibits both active and passive defensive traits. As highlighted earlier, the shell structure of $P$. maximus exhibits highly hierarchical cross-lamellar microstructure. This type of microstructure is responsible for increasing the mechanical strength of the shell by efficient energy dissipation (e.g. Meyers et al., 2008). It has been argued that about $60 \%$ of bivalve species and $90 \%$ of gastropod species display this microstructure, thus it seems that it is the most common structural spatial organisation occurring in the shells of molluscs (Barthelat et al., 2009; Salinas \& Kisailus, 2013). This hierarchical cross-lamellar microstructure has been thoroughly documented, for example, in queen conch (Strombus gigas) (Salinas \& Kisailus, 2013 and literature cited therein), ark clams (Arcidae), cockles (Cardiidae), sunset clams (Psammobiidae), Venus clams (Veneridae), Lucinidae, Tellinidae and many others (Chavan, 1969; Taylor et al., 1969; Popov, 1986). The detailed construction of hierarchical cross-lamellar structure combined with the description of energy dissipation mechanism were provided by Barthelat et al. (2009) and Espinosa et al. (2010). These data showed that the application of external forces to such shells instead of producing one large crack induce many minor channel cracks that are not dangerous to the soft tissues of the animal (see also Meyers et al., 2008). Therefore, hierarchical crosslamellar structure of $P$. maximus can be classified as a passive defensive trait against predators.

In contrast, the outer layer of $P$. maximus revealed a porous structure. It has been argued that this type of structure exhibits the lowest hardness in comparison with the other types of microstructures (Yang et. al., 2011a, 2011b, 2011c). However, such microstructure significantly reduces the weight of the shell, which is a prerequisite for effective swimming.

Indeed, it has been shown that P. maximus in the direct presence of predator can rapidly swim away by clapping their valves together and the expulsion of jets of water adjacent to the hinge line through the mantle edge (Baird, 1958; Ansell, 1969). The ability of pectinids to swim has been ascribed to anti-predator adaptation by Hayami (1991) and Hautmann (2004). Interestingly, $P$. maximus possesses eyes that are present on both the upper 


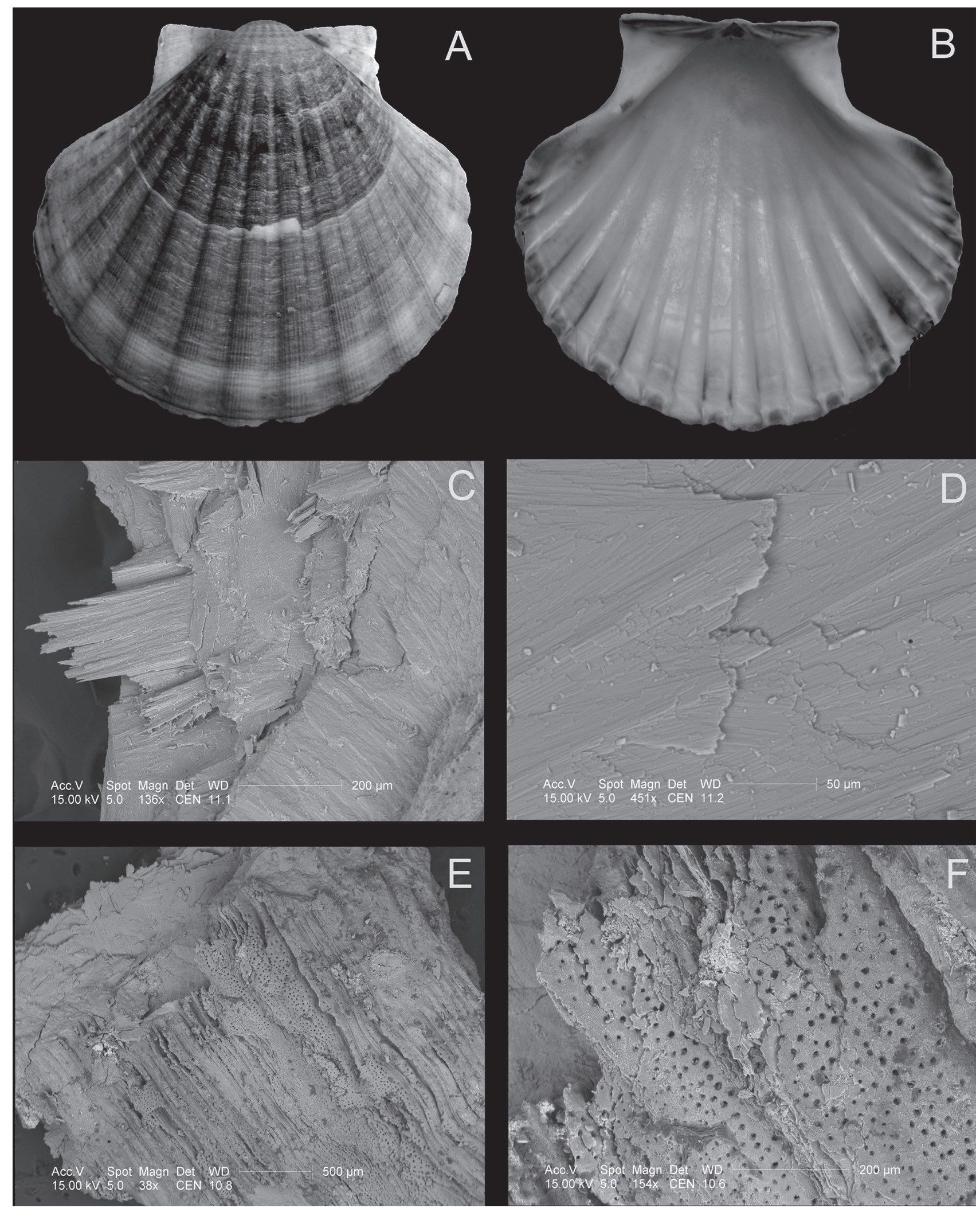

Figure 1. (A) Bottom valve of P. maximus (upper side), (B) bottom valve of P. maximus (lower side), (C) crossed-lamellar structure in the general plan, (D) crossedlamellar structure in magnification, (E) porous structure in the general plan and (F) porous structure in magnification. 
and lower valves. They are composed of proximal and distal cells acting as light intensity and movement detectors, respectively (Barber et al., 1967).

\section{Concluding remarks}

Recent pectinids possess many active and passive defensive adaptations against predators. Their complex shell microstructure plays significant role in both energy dissipation and reducing the shell weight. We suggest that their appearance in the Middle Triassic (Hautmann, 2010) and subsequent evolutionary success was probably related to increased predation pressure during the socalled Early Mesozoic Marine Revolution. Future microstructural studies on fossil pectinids are planned to test this hypothesis.

\section{References}

[1] Ansell A.D. 1969. Leaping movements in the Bivalvia. J. Mollus. Stud., 38, 5: 387-399.

[2] Baird R.H. 1958. On the swimming behavior of escallops (Pecten maximus L.). Proceedings of the Malacological Society of London, 33: 67-61.

[3] Barber V.C., Evans E.M., Land M.F. 1967. The fine structure of the eye of the mollusk Pecten maximus. Zeitschrift für Zellforschung und Mikroskopische Anatomie, 76, 3: 295-312.

[4] Barthelat F., Rim J.E., Espinosa H.D. 2009. A Review on the Structure and Mechanical Properties of Mollusk Shells. Perspectives on Synthetic Biomimetic Materials. [in:] B. Bhushan, H. Fuchs (eds.) Applied Scanning Probe Methods XIII, Biomimetics and Industrial Applications, 17-44, Springer.

[5] Bengtson S., Morris S.C. 1992. Early Radiation of Biomineralizing Phyla. [In:] J.H. Lipps, P.W. Signor (eds.) Origin and Early Evolution of the Metazoa, 447-481, Plenum Press, New York.

[6] Chauvaud L., Lorrain A., Dunbar R.B., Paulet Y.M., Thouzeau G., Jean F., Guarini J.M., Mucciarone D. 2005. Shell of the Great Scallop Pecten maximus as a high-frequency archive of paleoenvironmental changes. Geochemistry Geophysics Geosystems, 6, 8, doi: 10.1029/2004GC000890.

[7] Chavan A. 1969. Lucinacea. [In:] Moore R.C. (ed.) Treatise on Invertebrate Paleontology, 491-517, New York.

[8] Cuif J.P., Dauphin Y. 1996. Occurrence of mineralization disturbances in nacreous layers of cultivated pearls produced by Pinctada margaritifera var. cumingi from French Polynesia. Comparison with reported shell alterations. Aquatic Living Resources, 9: 187-193.

[9] Dyduch-Falinowska A., Piechocki A. 1993. Muszla. [In:] A. DyduchFalinowska, A. Piechocki (eds.) Mięczaki (Mollusca) - Małże (Bivalvia), 29-33, Wydawnictwo Naukowe PWN, Warszawa.

[10] Espinosa H.D., Juster A.L., Latourte F.J., Loh O.Y., Gregoire D., Zavattieri P.D. 2010. Tablet-level origin of toughening in abalone shells and translation to synthetic composite materials. Nature Communications, 2: 173, doi:10.1038/ncomms1172.

[11] Futuyma D.J. 2008. Koewolucja: rozwijanie interakcji międzygatunkowych. [In:] D.J. Futuyma (ed.) Ewolucja, 437-456, Wydawnictwa Uniwersytetu Warszawskiego, Warszawa.

[12] Grefsrud E.S., Dauphin Y., Cuif J.P., Denis A., Strand Ø. 2008. Modifications in microstructure of cultured and wild scallop shells (Pecten maximus). Journal of shellfish research, 27, 4: 633-641.

[13] Harper E.M., Skelton P.W. 1993. The Marine Mesozoic Revolution and epifaunal bivalves. Scripta Geologica, special issue 2: 127-153.

[14] Hautmann M. 2004. Early Mesozoic evolution of alivincular bivalve ligaments and its implications for the timing of the "Mesozoic marine revolution". Lethaia, 37: 165-172.

[15] Hautmann M. 2010. The first scallop. Paläontologische Zeitschrift, 84, 2: 317-322.
[16] Hayami I. 1991. Living and fossil scallop shells as airfoils: an experimental study. Paleobiology., 17: 1-18.

[17] Jackson D.J., McDougall C., Woodcroft B., Moase P., Rose R.A., Kube M., Reinhardt R., Rokhsar D.S., Montagnani C., Joubert C., Piquemal D., Degnan B.M. 2010. Parallel evolution of nacre building gene sets in molluscs. Molecular Biology and Evolution, 27, 3: 591-608.

[18] Jura C. 2005. Gromada: Małże - Bivalvia. [In:] C. Jura (ed.) Bezkręgowce - Podstawy Morfologii Funkcjonalnej, Systematyki i Filogenezy, 673686, Wydawnictwo Naukowe PWN, Warszawa.

[19] Katti K.S., Katti D.R., Mohanty B. 2010. Biomimetic Lessons Learnt from Nacre. [In:] A. Mukherjee (ed.) Biomimetics Learning from Nature, 193-216, Tech Rijeka.

[20] Kosnik M.A., Alroy J., Behrensmeyer A.K., Fürsich F.T., Gastaldo R.A., Kidwell S.M., Kowalewski M., Plotnick R.M., Rogers R.R., Wagner P.J. 2011. Changes in shell durability of common marine taxa through the Phanerozoic: evidence for biological rather than taphonomic drivers. Paleobiology, 37, 2: 303-331.

[21] Krebs C.J. 2011. Ewolucja i „wyścig zbrojeń”. [In:] C.J. Krebs (ed.) Ekologia - Eksperymentalna Analiza Rozmieszczenia i Liczebności, 27-28, Wydawnictwo Naukowe PWN, Warszawa.

[22] Meyers M.A., Chen P.Y., Lopez M.I., Seki Y., Lin A.Y.M. 2011. Biological materials: A materials science approach. Journal of the Mechanical Behavior of Biomedical Materials, 4, 5: 626-657.

[23] Meyers M.A., Yu-Min L.A., Chen P.Y., Muyco J. 2008. Mechanical strength of abalone nacre: Role of the soft organic layer. Journal of the Mechanical Behavior of Biomedical Materials, 1, 1: 75-85.

[24] Piechocki A. 2009. Gromada: Małże - Bivalvia. [In:] C. Błaszak (ed.) Zoologia - Bezkręgowce Tom I, 508-552, Wydawnictwo Naukowe PWN, Warszawa.

[25] Pokryszko B. 2009. Podtyp: Muszlowce - Conchifera. [In:] Błaszak C. (ed.) Zoologia - Bezkręgowce Tom I, 425-426, Wydawnictwo Naukowe PWN, Warszawa.

[26] Popov S.V. 1986. Composite prismatic structure in bivalve shell. Acta Palaeontologica Polonica, 31, 1-2: 3-28.

[27] Ragaini L., Di Celma C. 2009. Shell structure, taphonomy and mode of life of a Pleistocene ostreid from Ecuador. Bollettino della Società Paleontologica Italiana, 48, 2: 79-87.

[28] Raup D.M., Stanley S.M. 1984. Ekosystem morski. [In:] D.M. Raup, S.M. Stanley (ed.) Podstawy Paleontologii, 270-275, Państwowe Wydawnictwo Naukowe PWN, Warszawa.

[29] Salamon M.A., Niedźwiedzki R., Gorzelak P.,Lach R.,Surmik D. 2012. Bromalites from the Middle Triassic of Poland and the rise of the Mesozoic Marine Revolution. Palaeogeography, Palaeoclimatology, Palaeocology, 321-322: 142-150.

[30] Salinas C., Kisailus D. 2013. Fracture mitigation strategies in gastropod shells. JOM, 65, 4: 474-480. 
[31] Tackett L.S., Bottjer D.J. 2012. Faunal succession of Norian (Late Triassic) level-bottom benthos in the Lombardian Basin: implications for the timing, rate, and nature of the Early Mesozoic Marine Revolution. PALAIOS, 27: 585-593.

[32] Taylor J.D., Kennedy W.J., Hall A. 1969. The shell structure and mineralogy of the Bivalvia. Introduction. Nuculacea - Trigoniacea. Bulletin of the British Museum (Natural History). Zoology, Supplement, 3: $1-125$.

[33] Urbański J. 1989. Gromada: Bivalvia (Lamellibranchiata, Acephala, Pelecypoda) - małże (blaszkoskrzelne). [In:] E. Grabda (ed.) Zoologia - Bezkręgowce Tom I Część trzecia, 805-851, Wydawnictwo Naukowe PWN, Warszawa.

[34] Vendrasco M.J., Porter S.M., Kouchinsky A.V., Li G., Fernandez C.Z. 2010. Shell microstructures in early Mollusks. The Festivus, XLII, 4: 43-54.
[35] Vermeij G.J. 1977. The Mesozoic marine revolution: Evidence from snails, predators and grazers. Paleobiology, 3: 245-258.

[36] Vermeij G.J. 1987. Evolution and Escalation. An Ecological History of Life, 1-527. Princeton University Press, Princeton.

[37] Yang W., Kashani N., Li X.W., Zhang G.P., Meyers M.A. 2011a. Structural characterization and mechanical behavior of a bivalve shell (Saxidomus purpuratus). Materials Science and Engineering: C, 31: 724-729.

[38] Yang W., Zhang G.P., Liu H., Li X.W. 2011b. Microstructural characterization and hardness behavior of a biological Saxidomus purpuratus Shell. Journal of Materials Science \& Technology, 27, 2: 139-146.

[39] Yang W., Zhang G.P., Zhu X.F., Li X.W., Meyers M.A. 2011c. Structure and mechanical properties of Saxidomus purpuratus biological shells. Journal of the Mechanical Behavior of Biomedical Materials, 4: 15141530 . 